\title{
Is Foreign Direct Investment Inflow Market Seeking in Nigeria? An Error Correction Model Approach
}

\author{
Afolayan Olufunmilayo $\mathrm{T}^{*}$ and Tomiwa Fiwajomi T \\ General Studies Department, The Federal Polytechnic, Ilaro, Nigeria
}

DOI: $10.36348 /$ sjbms.2019.v04i09.005

| Received: 02.09.2019 | Accepted: 09.09.2019 | Published: 20.09.2019

*Corresponding author: Afolayan Olufunmilayo T

Abstract

The aim of this study is to examine the critical macroeconomic variables that determine the inflows of FDI in Nigeria over the period of 1990 to 2017 which past studies have not fully explored. Consequently, the study utilized data from UNCTAD World Bank database and CBN Statistical Bulletin and error correction model was used to address the objective of this study. However, the following are the crucial findings that originated from this study. The following are the crucial findings that the study discovered. The error correction term indicates that about $22 \%$ of total disequilibrium due to external shock in the previous year is corrected in the current year. The principal driver of FDI inflows in Nigeria is growth rate of the economy. While, market size only caused an insignificant FDI inflow in the short run. Therefore, FDI inflow in Nigeria is not market seeking. Furthermore, based on these findings, this study makes the following recommendations for the policy makers in Nigeria. The policy makers should embark on holistic approach that has the capacity to expand the country`s market size and ensure a double-digit growth rate of the economy. In the same vein, the policy measures that would guarantee sustainability of the FDI inflows through market size and growth rate of economy in the long run should be put in place by the policy makers in Nigeria.

Keywords: FDI, Market Size, Growth Rate, and Nigeria.

Copyright @ 2019: This is an open-access article distributed under the terms of the Creative Commons Attribution license which permits unrestricted use, distribution, and reproduction in any medium for non-commercial use (NonCommercial, or CC-BY-NC) provided the original author and source are credited.

\section{JEL Classification: F21, F23, F43,}

\section{INTRODUCTION}

The important role in which foreign direct investment plays in developing countries cannot be overemphasized. Most of the developing countries, especially Africa have extreme local investment due to the low saving habit of the people in these countries. In order to augment the vacuum created by the inadequate capital, some countries in Africa have embarked on various policies to attract FDI in the time past. It has been argued that FDI provides an avenue for the inflows of capital and technology that the host country lacks [1]. It is worth noting that in the past few decades, FDI generated about $20 \%$ of fixed capital formation in the developing economies of Africa, but in favour of oil rich countries [2].

However, Nigeria is one of the oil rich nations in Africa which has made the country to be of interest to the global investors. This justified the reason why $70 \%$ of FDI inflows in ECOWAS countries went to Nigeria in 2006. This implies that FDI inflows in Nigeria is more of natural resource seeking. In the recent times, despite the fact Nigeria is the sixth highest exporter of crude oil in the global market Nigeria has not been able to be on the same pace in attracting FDI inflows like most non-oil producing countries in the Asian continent. In the past few years FDI inflows in Nigeria have not been impressive. Explicitly, from 2011, FDI inflows fell from US $\$ 8.9$ billion to US $\$ 3.5$ billion in 2017. This shows that FDI inflows dropped by $61 \%$ in Nigeria in the last 7 years [3]. The sharp decline in FDI inflows in Nigeria in the recent time has generated an issue of concern among the scholars and the policy makers. Despite the fact that several studies have confirmed that major determinant of FDI inflows into Nigeria is oil and gas [4, 2]. Nevertheless, studies in some other quarters especially in newly emerging economies of Asia have identified some other critical variables such as sound investment policies and 
appropriate institution, low labour cost, domestic market size, infrastructure, gross capital formation. See Samol and Solifano [5], Jadhav [6], Jadhav and Katti [7], and Vijayakumar, Sridharan and Rao [8]. In view of the above, it is instructive to examine the impact of market size in determining the FDI inflows in Nigeria given the fact that Nigeria has the biggest market size in Africa. Therefore, this study will examine the relationship between the market size and FDI inflows in Nigeria in which the bulk of past studies have not yet explored holistically.

\section{LITERATURE REVIEW \\ Theoretical Review \\ Kojima's Japan FDI Model}

Kojima [9] employed macroeconomic approach hinged on factor endowment to enunciate the rise of FDI. While explaining FDI inflows, Kojima enumerated three different motives behind multinational enterprises` investment in abroad. These motives are resource, labour and market. Kojima regarded FDI as trade-oriented which originated from Japan, while antitrade for FDI from the USA. Consequently, Kojima utilized the $\mathrm{H}-\mathrm{O}$ and Rybczynski theory of comparative advantage to advance five propositions as the factors that propel FDI. Firstly, natural resource-seeking FDI was regarded as trade-oriented. Because of existence of comparative disadvantages in the home country, this makes MNEs to invest in goods that possess comparative advantage in host countries. As such the home country raises imports of its comparative disadvantage products. This results into growth in vertical specialization between primary products and manufactured products. In another perspective, labouroriented FDI was also viewed as trade-oriented. An increment in wages in industrialized countries brings about a comparative advantage in labour-based industries in developing countries. Due to this, it is highly beneficial and rational for a developed economy to site its traditional labour-intensive industries in countries where reward on labour is cheap. Therefore, investment that is labour-oriented is also exportoriented and not import substitution. Furthermore, market-oriented FDI could be conceptualized as tradeoriented. This occurs when tariffs induce FDI inflows in the host economy, trade oriented FDI arises. However, the American oligopolistic FDI orchestrated anti-trade FDI which occurs in market-oriented FDI. It is evident that anti-trade FDI arises when MNE investment in the host country becomes oligopolistic. Finally, based on the five propositions, Kojima submitted that Japanese FDI is trade-oriented because Japanese MNEs invest abroad by transferring their resources of comparative disadvantage to host countries with comparative advantage in similar industries. By and large, Japanese MNEs is benefited via investment in abroad, leading to structural adjustment and opening of markets in developing economies.

\section{Empirical Review}

This section reviewed the nexus between FDI inflows and other macroeconomic variables in Africa in general and Nigeria in particular with a view to assessing the perceptions of scholars regarding this subject matter over time.

Gui-Diby [10] utilized GMM Technique to assess the nexus between FDI and economic growth in 50 countries in Africa between 1980 and 1994. The author submitted that there was an inverse relationship between FDI and economic growth from 1980 to 1994. But reverse was the case from 1995 to 2009. It is instructive to state that the positive effect observed in the latter period is connected with the significant improvement in the business environment and the multiplier effect of export on these economies. Similarly, Saibu and Akinbobola [11] adopted a Vector Error Correction Modeling (VECM) while examining the linkage between globalization, FDI and economic growth in some selected countries in Africa. It was discovered from the study that trade liberalization and economic growth process have an insignificant relationship in SSA nations.

Aderemi Olayemi, Ebere and Adeniran [12] used Dynamic Ordinary Least Square and granger causality to investigate impact of security spending on foreign direct investment inflows in Nigeria between 1994 and 2016. The authors submitted that there was an existence of a positive relationship between the internal security spending and FDI inflows in Nigeria. Also a bidirectional causality flows from defense spending to FDI inflows in the country. Samol and Solifano [5] posited that government fiscal deficit/surplus was a key variable that motivated foreign direct investment inflow to an economy. While examining the relationship between economic freedom and economic growth in SAARC Member Countries, Mahmood, Azid, Chaudhry and Faridi [13] utilized econometrics model to discover that a negative relationship between government size and growth. Whereas financial, trade, investment, business, property rights, and freedom from corruption had a positive relationship with growth.

Consequently, Adeyeye, Akinuli and Ayodele [14] assessed the relationship between spending on security and FDI inflows in Nigeria between 1985 and 2015 with the application of Error Correction Model. It was discovered from the paper that the expenditure on security and inflation had a negative relationship with FDI. But, in the long run defense spending and FDI inflows have a direct relationship in the country. Isam [15] submitted that the motivation behind investment decision of foreign investors was presence of security, infrastructure and economic performance. Meanwhile, the author discovered political instability, unstable exchange rate, economic performance and unpredictable inflation as factors that discourage foreign investment. Azman-Saini, Baharumshah, and 
Law [16] examined the relationship between systemic, foreign direct investment, economic freedom and economic growth with aid of econometrics technique. It was discovered from the study that foreign direct investment and economic growth had an indirect positive relationship. Whereas in the host countries, the impact of FDI was contingent on position of economic freedom. This implies that the benefits a country derives from the inflows of cross border investment is a function of its level of economic freedom.

In summary, it could viewed from the reviewed past empirical studies are inconclusive about the nexus between FDI inflows and other macroeconomic variables in Nigeria. Hence, the importance of this study.

\section{METHODOLOGY}

Secondary data from different various sources were employed for this study. For instance data on FDI inflows were extracted from UNCTAD database published by the World Bank and data on other macroeconomic variables were extracted from CBN statistical bulletin 1990 to 2017. Eviews software was adopted run the data.

\section{Model Specification}

$$
\mathrm{FDI}=\mathrm{F}(\mathrm{MZ}, \mathrm{GR},)
$$

If the model (I) is log linearized, it results into model (II) as follows

$$
\text { LnFDIt }=\alpha_{0}+\alpha \mathrm{LnMZ} t+\beta \mathrm{GR} t+\mu \mathrm{i}
$$

\section{Estimation Techniques}

The study employs Augmented Dickey Fuller (ADF) and Philips-Perron (PP) unit root tests for the stationarity test of the data series and Johansen

cointegration test for testing the long run equilibrium among the variables and error correction model is estimated.

Therefore, in an explicit way the model to capture the analysis of this work could be stated thus:

$\Delta$ LnFDI $_{t}=\beta_{0}+\sum_{i=1}^{p} \beta_{11} \quad \Delta \quad \operatorname{LnFDI}_{t-1}+\sum_{i=0}^{p} \alpha_{1} \quad \Delta \quad \operatorname{LnMZ}_{t-1}+\Delta \beta_{1} G R_{t-1}+E_{C M} M_{t-1}+$

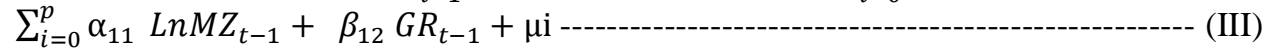

Where

FDI is FDI inflows which is measured in millions USD

MZ is used to denote the market size of the economy: the real GDP is used to proxy it and is measured in USD.

GR denotes the annual growth rate of economy and is measured in percentage

$\mu \mathrm{i}$ captures error term.

$\mathrm{t}=1990---------2017$.

$\alpha_{0}$ is an intercept and $\alpha, \beta$, are the slope parameters. Aprori expectation $\alpha, \beta,>0$.

\section{RESULT AND DISCUSSION}

Table-1: Descriptive Statistics of Annual Data Series (1990-2017)

\begin{tabular}{|l|l|l|l|}
\hline Descriptive Statistics & LMZ & LFDI & GR \\
\hline Mean & $7.8 \mathrm{E}+148$ & $3.58 \mathrm{E}+09$ & 5.217857 \\
\hline Median & $3.85 \mathrm{E}+13$ & $2.24 \mathrm{E}+09$ & 4.350000 \\
\hline Maximum & $2.2 \mathrm{E}+150$ & $8.92 \mathrm{E}+09$ & 33.70000 \\
\hline Minimum & $1.96 \mathrm{E}+13$ & $1.00 \mathrm{E}+09$ & -1.600000 \\
\hline Std. Deviation & $4.1 \mathrm{E}+149$ & $2.54 \mathrm{E}+09$ & 6.521989 \\
\hline Skewness & 5.003702 & 0.786992 & 3.070353 \\
\hline Kurtosis & 26.03704 & 2.337514 & 14.19066 \\
\hline Jargue-Bera & 735.9954 & 3.402366 & 190.0958 \\
\hline Probability & 0.000000 & 0.182468 & 0.000000 \\
\hline Sum & $2.2 \mathrm{E}+150$ & $1.00 \mathrm{E}+11$ & 146.1000 \\
\hline Sum. Sq. Deviation & $4.6 \mathrm{E}+300$ & $1.74 \mathrm{E}+20$ & 1148.481 \\
\hline Observation & 28 & 28 & 28 \\
\hline
\end{tabular}

Source: Authors` Computation (2019)

In econometric analyses it is important to factor in the assumptions of normality and asymptotic properties of data series. In view of the above, an effort has been made to examine the descriptive statistics of the data used to proxy the variables of interest in this study with a view to estimating the values of mean, median, Jargue-Bera and Kurtosis which are important parameters to establish the presence or otherwise of symmetrical nature of data set. It could be deduced from Table 1 that the values of mean and median of all the variables are not far from each other especially FDI and growth rate. This implies that the data series is fairly symmetrical in nature, because in a perfect 
Table-2: Unit Root Test

\begin{tabular}{|l|c|l|l|l|l|l|}
\hline \multirow{2}{*}{ Variables } & \multicolumn{3}{|c|}{ ADF Test } & \multicolumn{3}{c|}{ PP Test } \\
\cline { 2 - 7 } & Level & \multicolumn{1}{|c|}{$\mathbf{1}^{\text {st }}$ Diff. } & Remarks & Level & $\mathbf{1}^{\text {st }}$ Diff. & Remarks \\
\hline LFDI & $-3.699871^{* *}$ & $-3.711457 * *$ & $\mathrm{I}(1)$ & $-3.699871^{* *}$ & $-3.711457 * *$ & $\mathrm{I}(1)$ \\
\hline LMkT & $-3.699871^{* *}$ & -3.808546 & $\mathrm{I}(1)$ & $-3.699871 * *$ & -3.711457 & $\mathrm{I}(1)$ \\
\hline GrT & $-3.699871^{* *}$ & -3.711457 & $\mathrm{I}(1)$ & $-3.699871^{* *}$ & -3.711457 & $\mathrm{I}(1)$ \\
\hline
\end{tabular}

Source; Authors`Computation (2019) ***\%1 level

It is extreme impossible to rule out nonstationarity problem when it comes to time series data because these data are always trended in nature. The problem of non-stationarity is very critical in economic analysis because it could reduce the validity of forecast based on such data. As a result of this, an attempt has been made in this study to overcome this problem by using the standard Augmented Dickey-Fuller (ADF) and Phillips-Perron (PP) tests to examine the stationarity or otherwise of the data. However, the results of the estimated Augmented Dickey-Fuller (ADF) tests presented in table 2 show that the data employed for this work were not stationary in their native form. In other words, the data possessed a unit root.

Table-3: Johansen Cointegration Test (Trace Statistics) and (Maximum Eigenvalue)

\begin{tabular}{|l|c|l|l|l|l|}
\hline Null Hypothesis & Eigenvalue & Trace Statistics & P-value & Maximum Eigenvalue & P-value \\
\hline $\mathrm{r}=0$ & 0.475780 & 32.08560 & 0.0268 & 16.79194 & 0.1820 \\
\hline $\mathrm{r} \leq 1$ & 0.067928 & 1.828966 & 0.1762 & 3.841466 & 0.1762 \\
\hline $\mathrm{r} \leq 2$ & 0.404213 & 15.29366 & 0.0536 & 14.26460 & 0.0666 \\
\hline
\end{tabular}

Source; Authors` computation (2019)

The results of pre-estimation of data for the analysis show that the variables of interest possess a unit root. As such, the variables namely FDI, market size and growth rate of GDP could have a long run equilibrium relationship despite the short run deviation caused by a unit root problem. In order to examine the existence or otherwise of the long equilibrium relationship among these variable, this study utilized a multivariate cointegration test by Johansen and Juselius [18]. The findings from the multivariate cointegration analysis in the above table show the existence of at most one cointegrating vectors in the systems from the trace statistics and the maximal eigenvalue statistics. Hence, the variables of interest in this study possess a long run equilibrium relationship with one another. In view of the above, this study would adopt an error correction model estimate the speed of adjustment between short run disequilibrium and long run relationship that exists among these variables.

Table-4: VAR Lag Order Selection Criteria

\begin{tabular}{|c|c|c|c|c|c|c|}
\hline \multicolumn{7}{|c|}{ Sample: 19902017} \\
\hline \multicolumn{7}{|c|}{ Included observations: 26} \\
\hline Lag & $\log \mathbf{L}$ & LR & FPE & AIC & SC & HQ \\
\hline 0 & -255.1701 & NA & 84602.52 & 19.85924 & 20.00440 & 19.90104 \\
\hline 1 & -228.8508 & $44.54024 *$ & $22488.17 *$ & $18.52699 *$ & $19.10765 *$ & $18.69420^{*}$ \\
\hline 2 & -223.8896 & 7.251055 & 31724.71 & 18.83766 & 19.85382 & 19.13028 \\
\hline \multicolumn{7}{|c|}{\begin{tabular}{|l|l}
$*$ indicates lag order selected by the criterion & \\
\end{tabular}} \\
\hline \multicolumn{7}{|c|}{ LR: sequential modified LR test statistic (each test at 5\% level) } \\
\hline \multicolumn{7}{|c|}{\begin{tabular}{|l|l|l} 
FPE: Final prediction error & & \\
\end{tabular}} \\
\hline \multicolumn{7}{|c|}{ AIC: Akaike information criterion } \\
\hline \multicolumn{7}{|c|}{ SC: Schwarz information criterion } \\
\hline HQ: 1 & nnan-Quinn & ormation cri & ion & & & \\
\hline
\end{tabular}

Unrestricted Vector Autoregression (VAR) by lag selection criteria was modeled to the time series data in order to determine the optimal number of lags required for the model. Table- 4 indicates that the lowest value for each estimator falls under lags one (1) based on the result of all the information criteria.

Table-5: Parsimonious Short Run and Long Run Regression Estimates Dependent Variable: LFDI

\begin{tabular}{|c|c|c|c|c|c|c|c|}
\hline Variables & Coefficient & t-statistics & P-value & Variable & Coefficient & t-statistics & P-value \\
\hline LFDI(-1) & $-0.354557 *$ & 1.8 & 0.0821 & ECM & $-0.225886^{* *}$ & 2.6 & 0.0162 \\
\hline $\mathrm{D}(\mathrm{LMZ}(-1)$ & 0.001104 & 1.1 & 0.2714 & LMKTZ(-1) & $-0.002582 *$ & 1.8 & 0.0869 \\
\hline $\mathrm{D}(\mathrm{GR}(-1)$ & -0.012199 & 1.2 & 0.2318 & GRT(-1) & $0.030856 * *$ & 2.5 & 0.0190 \\
\hline $\mathrm{C}$ & 0.019213 & 0.2 & 0.8588 & & & & \\
\hline
\end{tabular}

Source: Authors` Computation (2019) *Significant at 10\%, **Significant at 5\%, * 
Table-5 presents the short run and long run estimates of the relationship between the FDI, market size and growth rate in Nigeria. It is important to state that the error correction term, ECM (-1) has a negative sign and significant with the absolute value of 0.22 . This shows that all the variables converged in the long run as the cointegration test reinforced it earlier. Meanwhile, the coefficient of the error term shows that the speed of adjustment from the short run to long-run is about $22 \%$ error committed in the previous year is corrected in the current year. Consequently, FDI inflows and market size have an insignificant positive relationship in the short run but the relationship became negative in the long run which is significant at $10 \%$ level of significance. This implies that a unit change in market size reduces FDI inflows by $0.2 \%$ inflows in FDI inflow in the country. Therefore, it could be concluded that FDI inflows in Nigeria is not market seeking in the long run. This study contradicts the submissions of Jadhay [19], Mughal and Akram [20], Asiedu [21] and Asiedu [22] in related studies. However, FDI inflows and growth rate of the economy have an insignificant negative relationship in the short run whereas the relationship became positive and significant at $5 \%$ level of significance in the long run. This implies the rate of economic growth could propel the inflow of FDI in Nigeria.

\section{Diagnostic and Stability Tests}

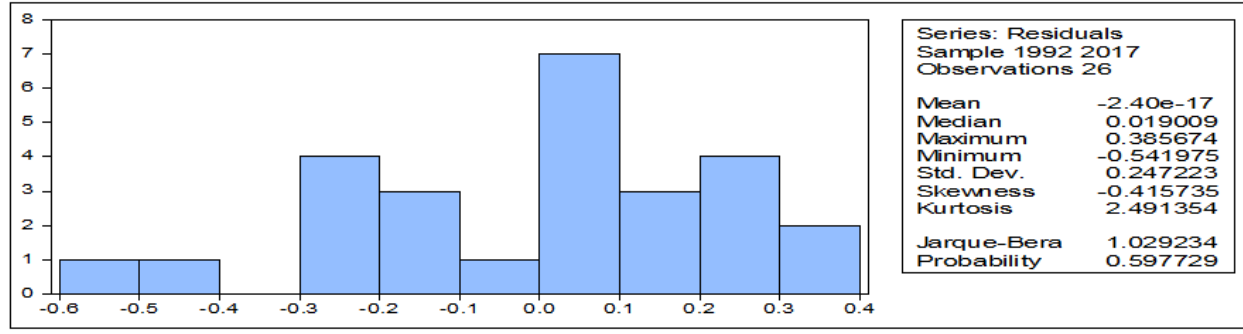

Fig-1: Test results for normality

The results in the above figure show that skewness is -0.415735 and kurtosis is 2.491354 . Meanwhile, the JB test indicates 1.029234 with a corresponding probability value not significant at $5 \%$ critical value. Kurtosis is indicated to be less than three which proves that the data are normally distributed.

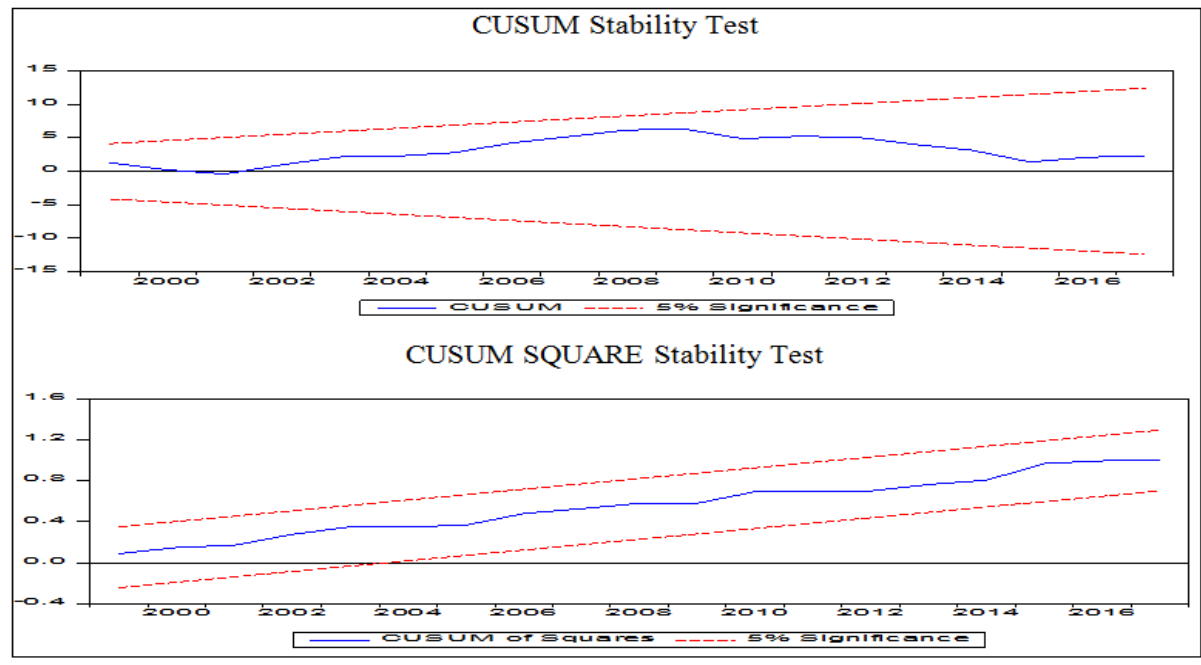

Fig-2: Stability Tests

This study further established the appropriateness of the short run (parsimonious) model. This necessitated the examination of various stability tests (Cumulative Sum (CUSUM) and Cumulative Sum of squares (CUSUMSQ) on the residual of the short run model. From the results of cumulative sum (CUSUM) and cumulative sum of squares (CUSUMSQ) tests in the above figure imply that the residuals of the errorcorrection model lies within the critical bounds of five percent significant level. This shows the stability of estimated parameters over the period 1990-2017. Hence, the model was reasonably specified.

\section{CONCLUSION AND RECOMMENDATIONS}

This study examined the short run and long relationship between FDI inflows and market size of the Nigerian economy over the period of 1990 to 2017. Consequently, the following are the crucial findings that the study discovered. The error correction term indicates that about $22 \%$ of total disequilibrium due to external shock in the previous year is corrected in the 
current year. Therefore, it will take about four (4) years for the system to adjust back to its long run equilibrium path. The principal driver of FDI inflows in Nigeria is growth rate of the economy. While, market size only caused an insignificant FDI inflow in the short run. Therefore, FDI inflow in Nigeria is not market seeking. Furthermore, based on these findings, it is instructive for this study to make the following recommendations for the policy makers in Nigeria. The policy makers should embark on holistic approach to that has the capacity to expand the country`s market size and ensure a double-digit growth rate of the economy. In the same vein, the policy measures that would guarantee sustainability of the FDI inflows through market size and growth rate of economy in the long run should be put in place by the policy makers in Nigeria.

\section{REFERENCES}

1. Olusanya, S. O. (2013). Impact of foreign direct investment inflow on economic growth in a pre and post deregulated Nigeria economy. A Granger causality test (1970-2010). European Scientific Journal, 9(25), 335-56.

2. AFDB, OECE, UNDP and UNECA. (2011). African Economic Outlook 2011: Africa and its emerging partners. African Development Bank, Tunis, Tunisia

3. UNCTAD. (2018). World investment Report 2018 published by the United Nations on TradeandInvestmentavailableatunctad.orgDATA\% 20on\%20FDI\%20BRICS\%201.htm.

4. Enoma, A., \& Mustafa, I. (2011). The Impact of Financial Sector Reforms on Non-Oil Export in Nigeria. Journal of Economics, 2(2), 115-120.

5. Samol A., \& Solifano, A. (2014). Private Investment and Macroeconomic Adjustment: A survey. World Bank Research, 7(2).

6. Jadhav, P. (2012). Determinants of foreign direct investment in BRICS economies: Analysis of economic, institutional and political factor. Procedia-Social and Behavioral Sciences, 37, 5-14.

7. Jadhav, P., \& Katti, V. (2012). Institutional and Political Determinants of Foreign Direct Investment: Evidence from BRICS Economies. Poverty \& Public Policy, 4(3), 49-57.

8. Vijayakumar, N., Sridharan, P., \& Rao, K. C. (2010). Determinants of FDI in BRICS Countries: A Panel Analysis. International Journal of Business Science and Applied Management, 5(3), $1-13$.

9. Kojima, K. (1973). A macroeconomic approach to foreign direct investment. Hitotsubashi Journal of Economics, 14(1), 1-21.

10. Gui-Diby, S. L. (2014). Impact of foreign direct investments on economic growth in Africa: Evidence from three decades of panel data analyses. Research in economics, 68(3), 248-256.
11. Saibu, M., \& Akinbobola, T. (2014). Globalization, Foreign Direct Investment and Economic Growth in Sub Saharan Africa. Journal of Economics and International Finance, 6(3), 6268

12. Aderemi, T. A., Olayemi, H. O., Ebere C. E., \& Adeniran, A. A. (2018). Security Spending and Foreign Direct Investment Inflows: Evidence from the Nigerian Economy. IOSR Journal of Humanities and Social Sciences (IOSR-JHSS), 23(11), 29-35.

13. Mahmood, K., Azid, T., Chaudhry, I. S., \& Faridi, M. Z. (2010). Impact of Economic Freedom on Economic Growth: The Case of Some Selected SAARC Member Countries. International Research Journal of Finance and Economics, 52, 7-16.

14. Adeyeye, P. O., Akinuli, B. O., \& Ayodele, S. O. (2016). The Nexus between Security Expenditure and Foreign Direct Investment in Nigeria. IOSR Journal of Business and Management (IOSRJBM), 18(11), 83-89.

15. Isam, S., \& Darwazeh, I. (2010). Simple DSPIDFT techniques for generating spectrally efficient FDM signals. In 2010 7th International Symposium on Communication Systems, Networks \& Digital Signal Processing (CSNDSP 2010) (pp. 20-24). IEEE.

16. Azman-Saini, W. N., Baharumshah, A. Z., \& Law, S. H. (2010). Foreign Direct Investment, Economic Freedom and Economic Growth: International Evidence. Economic Modelling, 27(5), 1079-1089.

17. Karmel, P. H., \& Polasek, M. (1980). Applied statistics for economists.

18. Johansen, S., \& Juselius, K. (1990). Maximum likelihood estimation and inference on cointegration - with applications to the demand for money. Oxford Bulletin of Economics and statistics, 52(2), 169-210.

19. Jadhav, S. P., Kemere, C., German, P. W., \& Frank, L. M. (2012). Awake hippocampal sharpwave ripples support spatial memory. Science, 336(6087), 1454-1458.

20. Mughal, M. M., \& Akram, M. (2011). Does market size affect FDI? The Case of Pakistan. Interdisciplinary Journal of Contemporary Research in Business, 2(9), 237247.

21. Asiedu, E. (2006). Foreign Direct Investment in Africa: Role of Government Policy, Institutions and Political Instability. World Economy, 29(1), 63-77.

22. Asiedu, E. (2004). Foreign direct investment in Africa: the role of natural resources, market size, government policy, institutions and political instability. Working Paper Series, University of Kansas. 